\title{
Redesign of E-Commerce Mobile Application with Design Thinking Method: A Case Study of RP2, Online Household Retailer
}

\author{
Natalia Limantara $^{1 *}$, Renaldi ${ }^{2}$, and Cynthia Filicia ${ }^{3}$ \\ ${ }^{1-3}$ Information Systems Department, School of Information Systems, Bina Nusantara University \\ Jln. K. H. Syahdan No. 9, Jakarta Barat 11480, Indonesia \\ 1'nlimantara@binus.edu; ${ }^{2}$ renaldi002@binus.ac.id; ${ }^{3}$ cynthia.filicia@binus.ac.id
}

Received: $7^{\text {th }}$ December 2020/ Revised: $10^{\text {th }}$ February 2021/ Accepted: $10^{\text {th }}$ February 2021

\begin{abstract}
How to Cite: Limantara, N., Renaldi, \& Filicia, C. (2021). Redesign of E-Commerce Mobile Application with Design Thinking Method: A Case Study of RP2, Online Household Retailer. ComTech: Computer, Mathematics and Engineering Applications, 12(2), 89-98. https://doi.org/10.21512/comtech.v12i2.6851
\end{abstract}

\begin{abstract}
RP2 is one of the growing e-commerce sites in Indonesia offering products for home and living. Recently, RP2 launches a mobile application to reach users by using mobile devices to facilitate purchases on RP2. However, the development of this mobile application has not been through a good application development process, so several weaknesses are found. The aim of the research was to redesign the RP2 mobile application using the design thinking method. The method had five stages: empathize, define, ideate, prototype, and test. However, the research only focused on the first four stages. Moreover, a survey using a questionnaire and interviews were done with 34 users of the RP2 mobile application. The research results are a prototype of the RP2 mobile application, which has been tailored to users' needs and the project owner's input. Changes have been made to the RP2 mobile application using the design thinking method. Changes are applied in several views, such as home, navigation and notifications, search bar, Product Detail Page (PDP), cart and payment, and profiles. With these changes, it is expected that users of the RP2 mobile application will increase, so the number of transactions through the RP2 mobile application will increase too.
\end{abstract}

Keywords: e-commerce, mobile application, design thinking method

\section{INTRODUCTION}

In this modern era, smartphones have become part of everyday life in Indonesia. The number of smartphone users and various mobile applications continues to grow over time. A functional and elegant mobile application enhances the daily life of its users. The Internet began to enter Indonesia in 1990. In fact, over time, Indonesia has become one of the largest Internet users in the world. Based on the results of a survey conducted by the Indonesia Internet Service Provider Association (Asosiasi Penyelenggara Jasa Internet Indonesia (APJII)), the growth of Internet users in Indonesia has reached 143,26 million out of Indonesia's total population of 262 million. Internet users increased by 22,5 million in 2015-2016. Meanwhile, in 2016-2017, it increased by 10,56 million users (Asosiasi Penyelenggara Jasa Internet Indonesia, 2018).

The current development of the Internet also influences the changes in the industry. One example is the development of the online shopping industry. Many new channels have emerged for people to shop over the Internet. With these online purchases, people can make transactions anywhere and anytime. In 2018, the average spending for daily needs via the Internet by Indonesians was US $\$ 89$, excluding travel and digital media spending, which involved 100 million Indonesians. This value was $30 \%$ more than the previous year, making Indonesia the fastest growing online market (Kemp \& Moey, 2019).

The number of online shoppers in Indonesia is targeted to reach 119 million by 2025. Local e-commerce, such as Tokopedia, Traveloka, Bukalapak, and Gojek, dominates the market. They represent four of seven ASEAN Unicorns. The development of e-commerce in Indonesia is supported by the development of smartphones, growing middleclass economy, direct investment from foreign investors, and development of digital payments. One of 
the daily needs that people buy online is furniture and household appliances. In 2018, the total expenditure in this sector was US\$1.674 (the fourth after fashion and beauty, electronics and physical media, and food and personal care) (Kemp \& Moey, 2019).

With the mentioned conditions, the researchers choose to review one of the furniture sellers in Indonesia. It has just launched a new sales channel through a mobile application. The company name is RP2. Based on the interview, RP2 is a retail store that sells a wide variety of furniture and appliances. In addition to having physical stores in Indonesian malls, RP2 has started to develop its online sales channels through a website or mobile application. RP2 has more than ten thousand products in ten different categories, focusing on home and living products like various household needs, kitchen, bed and bath needs, home improvement, furniture, automotive, hobbies and lifestyle, health, sports, electronics, and toys and baby needs.

To compete with other competitors, companies need new methods to promote their products. One of the ways is by applying technology in the business (Setiawan, Muna, Arumi, \& Sukmasetya, 2020). In June 2019, RP2 launched a mobile application. The development of this mobile application is only carried out based on the perspective of the user interface designer and developer team. Before the development takes place, the research stage is not carried out, so some aspects still do not meet the standards. In previous research, user experience is considered by e-commerce users (Kumaresh, Haran, \& Jarret, 2021). The research applies the design thinking method to redesign the RP2 mobile application. With this change in the user interface design, it is expected that the application will be more user-friendly and can attract more users to make transactions through this mobile application (Mitchell, 2017). Based on previous research, user interface design has become one of the factors that influence users' trust. A website navigation design that is easy to use will increase the level of customer trust. In addition, it will also increase customer loyalty to the company (Bilgihan, 2016). So, with the redesign of this mobile application, it is expected that the sales revenue will also increase (Mitchell, 2017).

\section{METHODS}

The methodology applied in the research is the design thinking method. Design thinking is a humancentered methodology for creative problem-solving. This method prioritizes users' empathy to lead to solutions (Kamran \& Dal Cin, 2020). The design thinking method in the research is based on the design thinking method discovered by the Hasso Plattner Institute of Design at Stanford University in 2005. This method has five stages: empathize, define, ideate, prototype, and test (Pham, Fucci, \& Maalej, 2018). Figure 1 shows the design thinking method. However, the research will only focus on the first four stages.

In the first stage of emphasizing, the researchers must understand the users and know the users' problems. At this stage, the researcher will use the User Experience Questionnaire (UEQ) to get input from users. Moreover, interviews will be conducted to obtain more in-depth information. In the next stage, defining, the researcher must deeply understand the users' problems and create a scope for the problems to be solved. The third stage is ideating. Researchers begin to generate ideas to solve problems. After getting the idea, the researchers begin to put the idea into a real prototype. This prototype serves to test the functionality of the system more easily. The last stage is a test that researchers use to get feedback from users (Dam \& Siang, 2020). The application of design thinking of Hasso Plattner allows the stages of each process not to be run sequentially, but the stages can return to the previous stage (Tschimmel, 2012).

\section{RESULTS AND DISCUSSIONS}

In the first stage (empathize), researchers use UEQ to discover the problems faced by users with a current mobile application. The main purpose of the UEQ is to measure the user experience when using the application quickly and accurately. The UEQ considers aspects of pragmatic and hedonic quality (Schrepp, Hinderks, \& Thomaschewski, 2014). It also has 6 aspects that will be measured through 26 questions. The first aspect is attractiveness. The product must look attractive, fun, friendly, and comfortable. The

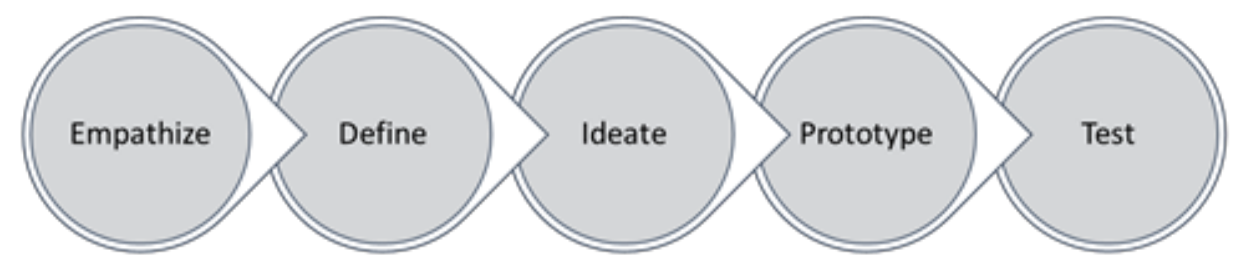

Figure 1 Design Thinking Method 
second aspect is efficiency. Users must perform the tasks with the product quickly, efficiently, and in a pragmatic manner. The third aspect is perspicuity. Products must be easy to understand, clear, simple, and easy to learn. The fourth aspect is dependability. Interactions with the product must be predictable, safe, and meet the users' expectations. The fifth aspect is stimulation that using the product should be engaging and motivating. The last aspect is a novelty. Products must be innovative, inventive, and creatively designed (Schrepp, Hinderks, \& Thomaschewski, 2017). UEQ can evaluate the user experience of a product quickly and efficiently. Each item will be assessed using two contradictory terms (Mushthofa, Sabariah, \& Effendy, 2018). Figure 2 displays the overall UEQ.

This questionnaire is given to current users of the RP2 mobile application to get their opinions about the application. Then, the questionnaire will be delivered in Indonesian to avoid bias. The results of the questionnaire that have been obtained will be processed using the data processing template that has been provided by (Schrepp et al., 2014). The results of this UEQ will be used as the basis for conducting interviews to change the appearance of this RP2 mobile application.

The UEQ questionnaire is completed by 34 respondents aged between 25 and 34 years. From the data, it can be concluded that all aspects in UEQ still score below average, with the novelty aspect having the lowest score. Based on previous research, aspects, such as efficiency and ease of use, are the factors that affect user trust in an e-commerce application (Casare, Da Silva, Basso, \& Moraes, 2021). The results of UEQ data processing can be seen in Table 1 and Figure 2.

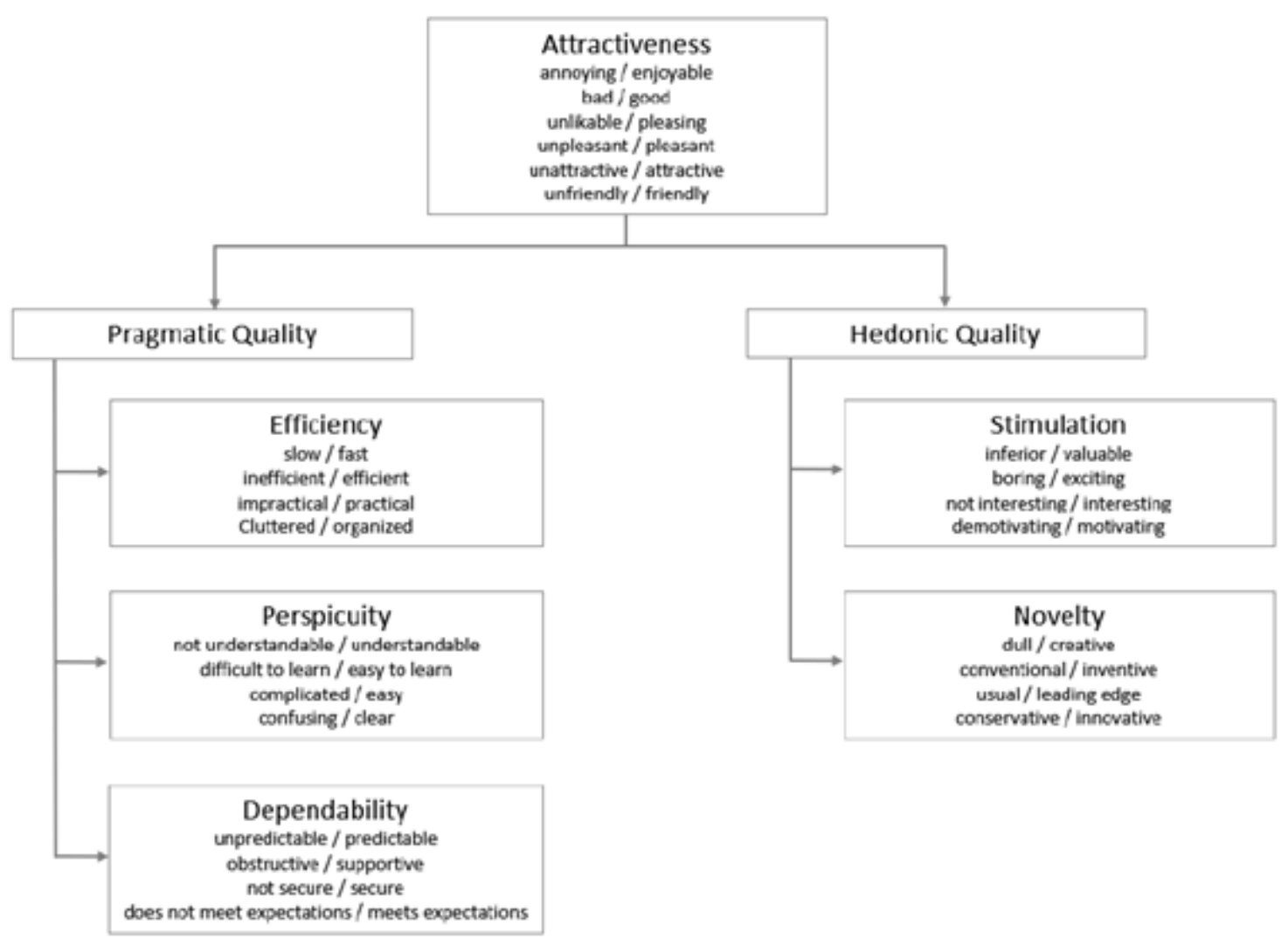

Figure 2 User Experience Questionnaire

Table 1 UEQ Result

\begin{tabular}{llll}
\hline Scale & Mean & Comparison to Benchmark & Interpretation \\
\hline Attractiveness & 0,78 & Below Average & $50 \%$ of results are better, and $25 \%$ of results are worse \\
Efficiency & 0,77 & Below Average & $50 \%$ of results are better, and $25 \%$ of results are worse \\
Perspicuity & 0,77 & Below Average & $50 \%$ of results are better, and $25 \%$ of results are worse \\
Dependability & 0,92 & Below Average & $50 \%$ of results are better, and $25 \%$ of results are worse \\
Stimulation & 0,70 & Below Average & $50 \%$ of results are better, and $25 \%$ of results are worse \\
Novelty & 0,40 & Below Average & $50 \%$ of results are better, and $25 \%$ of results are worse \\
\hline
\end{tabular}


To get more detailed information on the UEQ result, the researchers conduct interviews with several users ranging from 25 to 34 years old. Information on this RP2 mobile application is obtained from the results of the interview. Users feel that the user interface of the RP2 mobile application is not structured yet. In addition, the layout of the user interface components is cluttered and less attractive. In addition, at this stage, an interview is also held with the project leader to find out the direction of the board of directors on the development of this RP2 mobile application.

Based on the information obtained from questionnaires and interviews, the researchers continue the second stage of design thinking (define). The researchers create a person that represents the types of users of the RP2 mobile application. A persona is a description of the user that describes the goals, interests, and abilities. Persona must display information, such as name, occupation, family, gender, age, ethnicity, education, socioeconomic status, goals, life histories, and tasks performed (Valentim, Silva, \& Conte, 2017). Persona is essential in designing user-oriented applications. The researchers show two personas to describe the users of this RP2 mobile application. The first persona in Figure 3 shows a user who is busy because of the demands of his job. Therefore, this user needs an application that offers alternative delivery and low prices compared to other competitors. Meanwhile, the second persona in Figure 4 shows the user who has a job as a drop shipper. Therefore, these users look for products with low prices and large quantities. It also includes the discounts offered.

The next stage is the ideating stage. This stage is based on the defining stage and focuses on creating ideas and details. Table 2 (see Appendix) summarizes the problems found from the previous stages as well as the proposed solutions.

In general, the obtained recommendations include improvements to the appearance, layout, structure, and additional features that will be applied to the following RP2 mobile application home pages, navigation, notifications, search bar, Product Catalog Page (PCP), Product Detail Page (PDP), cart, payment, and profile. Home is the first page that appears when the RP2 application is opened. Then, the navigation bar is a frame that contains navigation menus with their respective functions. In the RP2 mobile application, the navigation bar is located at the bottom of the home page. Moreover, notifications on RP2 serve as a place to find out the latest promotions. The search bar is a combination of an input field and a submit button. It is used to search for items on the RP2 mobile application. Then, PCP displays a catalog of items sold by RP2. Meanwhile, PDP shows detailed information of an item, such as product descriptions, specifications, and available shipping information. Cart is a shopping cart that contains items to be purchased before being processed to the payment page. Next, the payment page contains the process of choosing a shipping method and picking up goods to complete the payment. The profile page has users' information. In addition, there are users' wish lists, membership information, exchange points, and others.

\section{Bella}

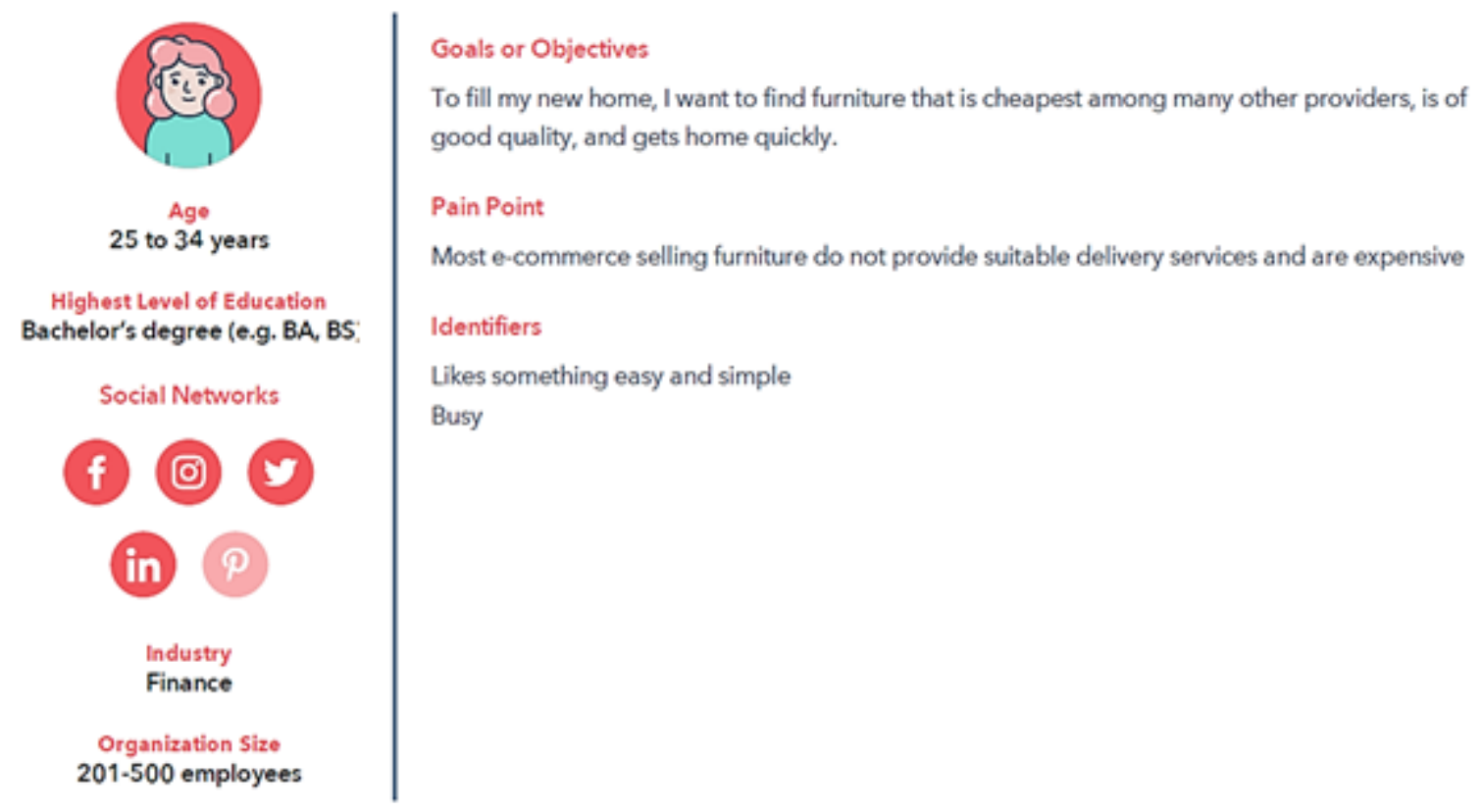

Figure 3 Persona 1 


\section{Christian}

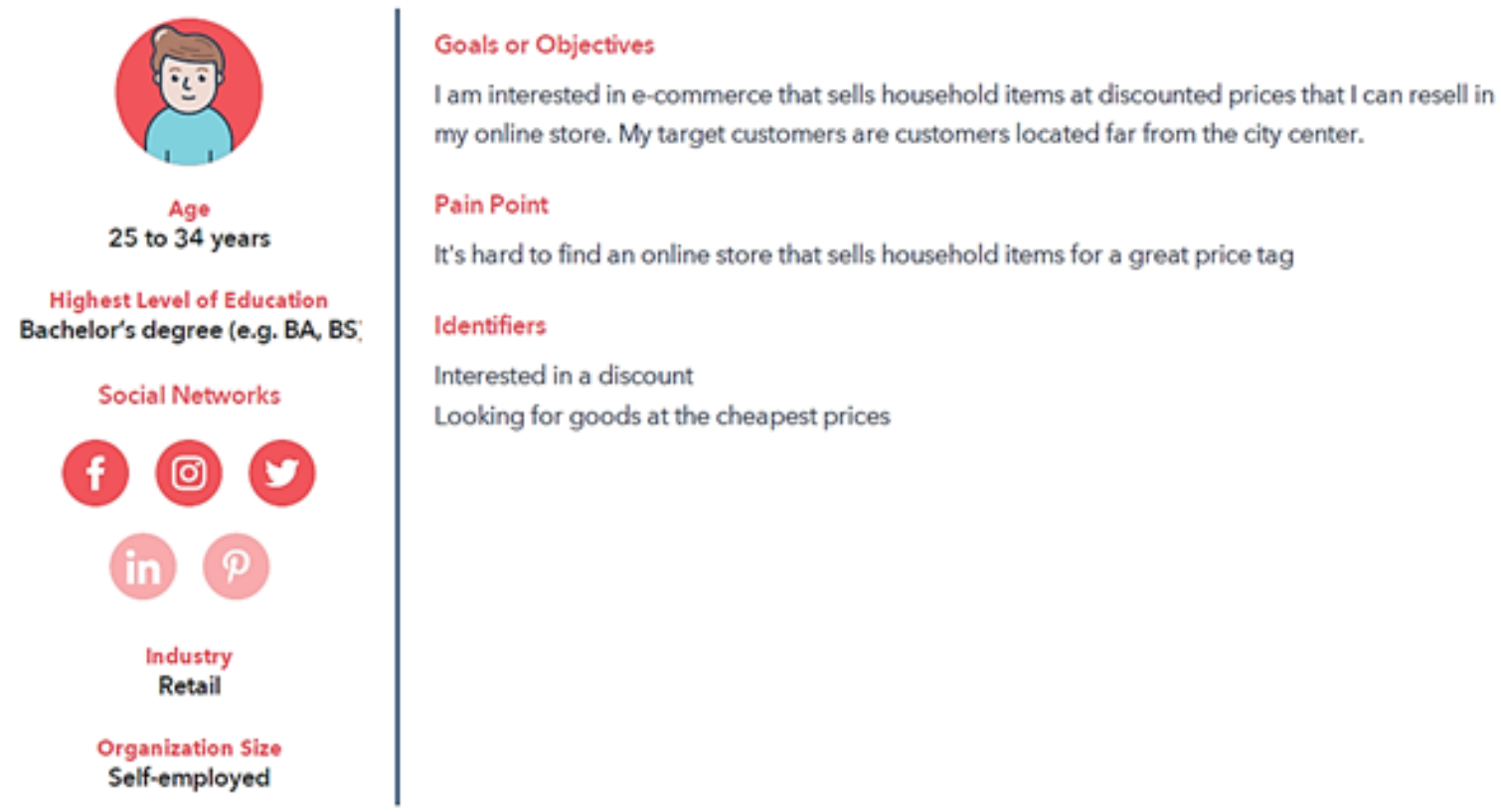

Figure 4 Persona 2
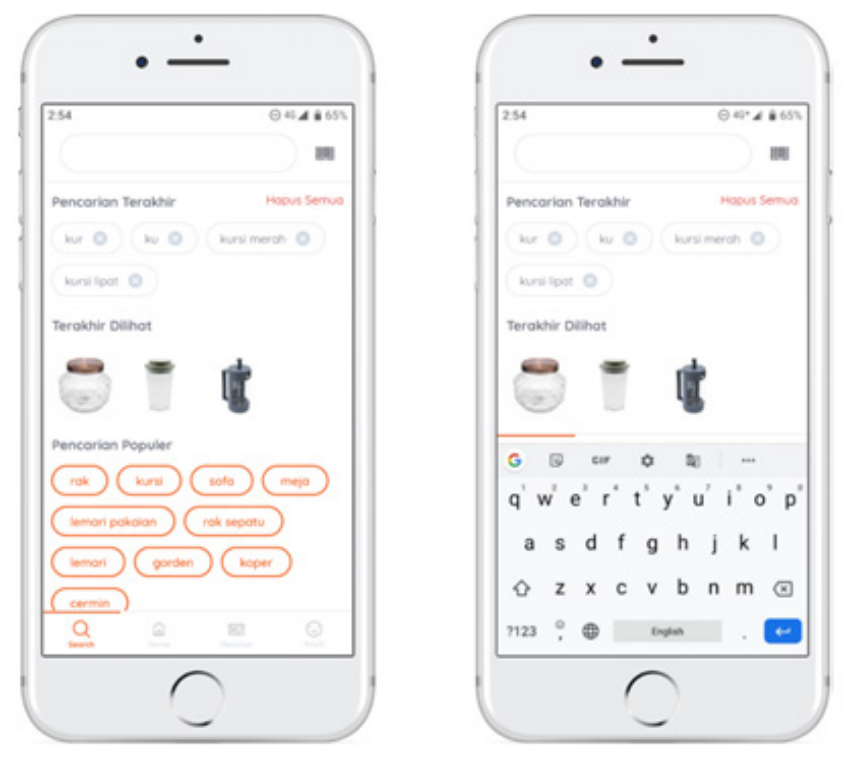

Figure 5 Old User Interface of Search Feature

The next stage of design thinking is to make a prototype of the RP2 mobile application. One of the changes made is in the search feature. Figure 5 shows the search screen used by the current RP2 mobile application, and Figure 6 is the new view of the search feature. In Figure 6, the search bar gives the recommendation to inspire users. Then, the position of popular search is moved to the second section and given the original image to provide more information to users about that category. In Figure 5, the last- seen section only displays product images. Then, it is converted into a product card that displays the product brand and name, as shown in Figure 6.
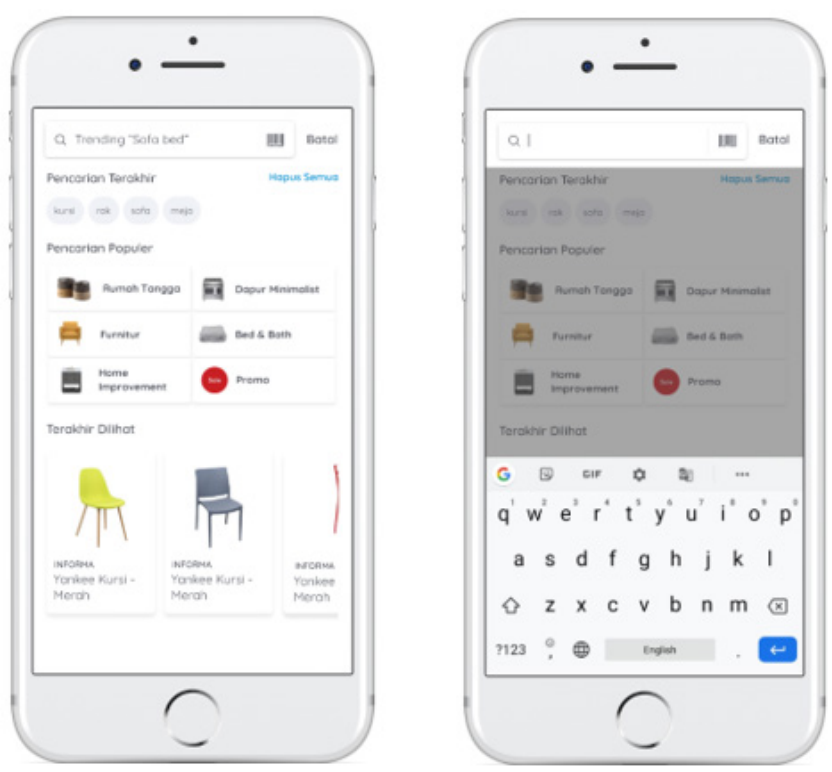

Figure 6 New User Interface of Search Feature

In the PCP, when the users select a category, the main view of the category page will display a banner containing images from that category. The goal is to make the display more attractive and clarify the illustration. This banner can be seen in Figure 7. 
However, this feature is not available in the current RP2 mobile application. In addition, the sub-category display, which is originally in a drop-down menu, has been changed to a slider to save space and help users to stay focused on their initial search goal.

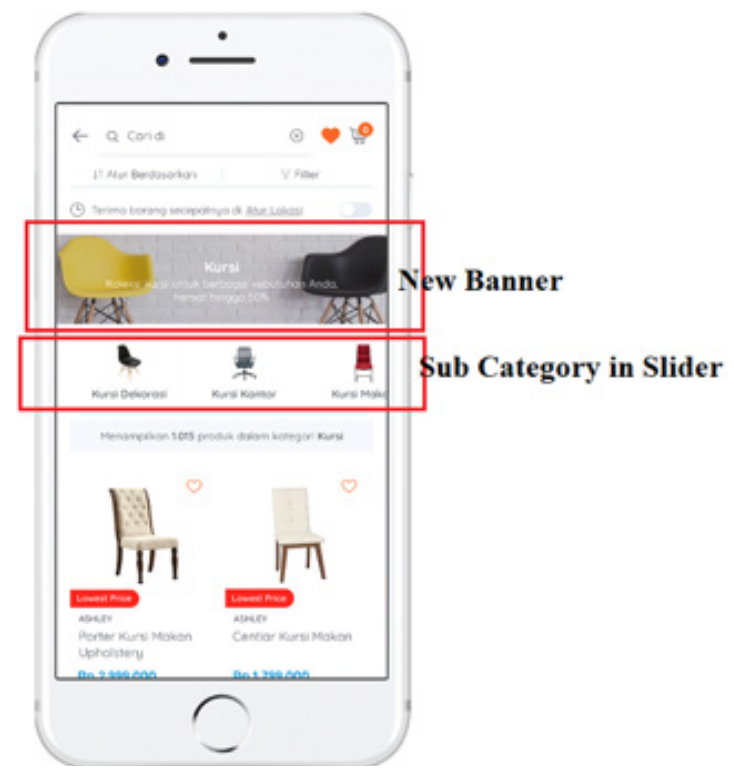

Figure 7 New User Interface of Category

Figure 8 shows that the PCP is displayed with more specific information than before by adding tags according to product specifications, such as the lowest price. In addition, changes are made in displaying product names and brands. In the new appearance, the brand and product names are shown in a different line. The goal is for users to differentiate brands and product specifications easily.

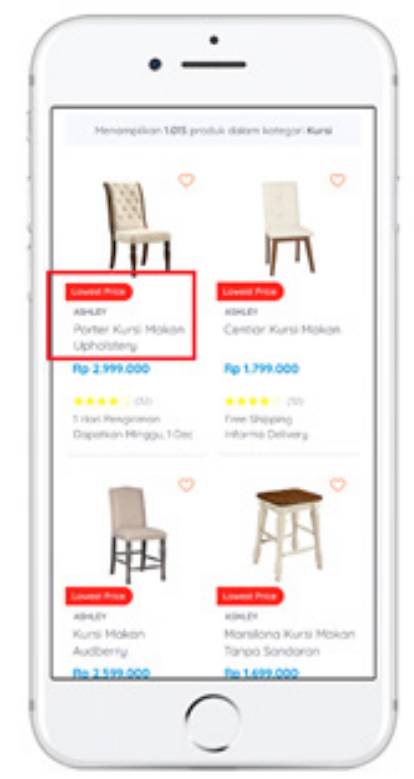

Figure 8 New User Interface of Product Card Page

Moreover, the filter feature is optimized by bringing up frequently used or popular filters on the main page, as shown in Figure 9 on the right. Therefore, it shortens the process of finding items. In addition, the arrangement has also been changed to be shorter on one page, so users do not have to scroll to see all the existing filters, as shown in Figure 9 on the left.
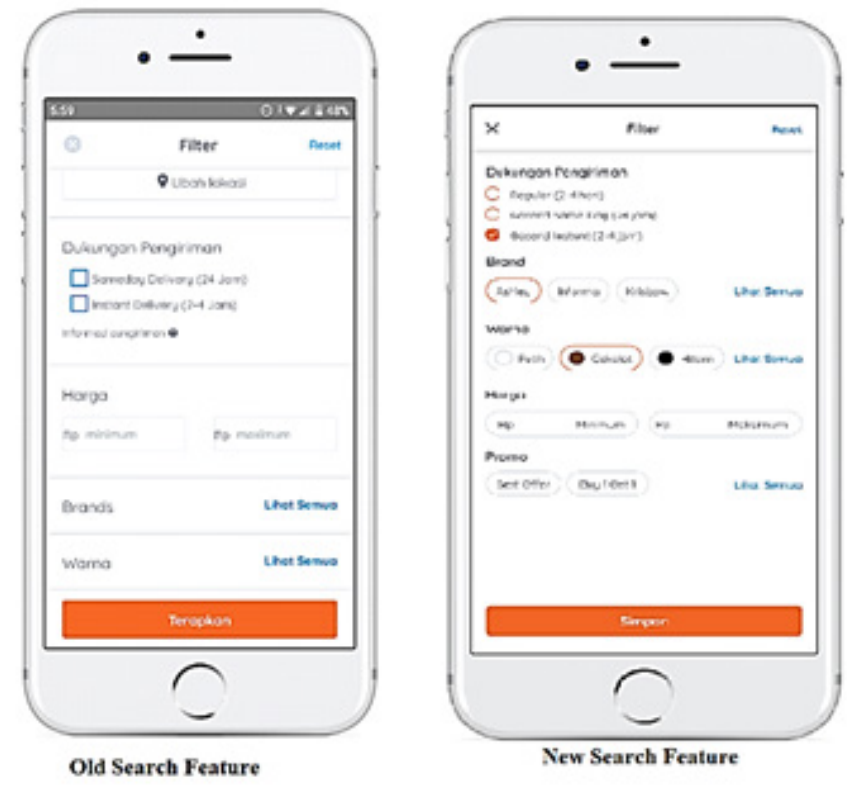

Figure 9 Search Feature

Next, the delivery information page is changed to a tab form. The first tab contains delivery information, and the second tab has information about picking up items at the store. The first tab will display information about the delivery address, courier options, delivery fee, and estimated items arriving at the location. Meanwhile, the second tab will contain information on the store that can be selected if the customer wants to pick up items directly at the store. This new user interface can be seen in Figure 10.
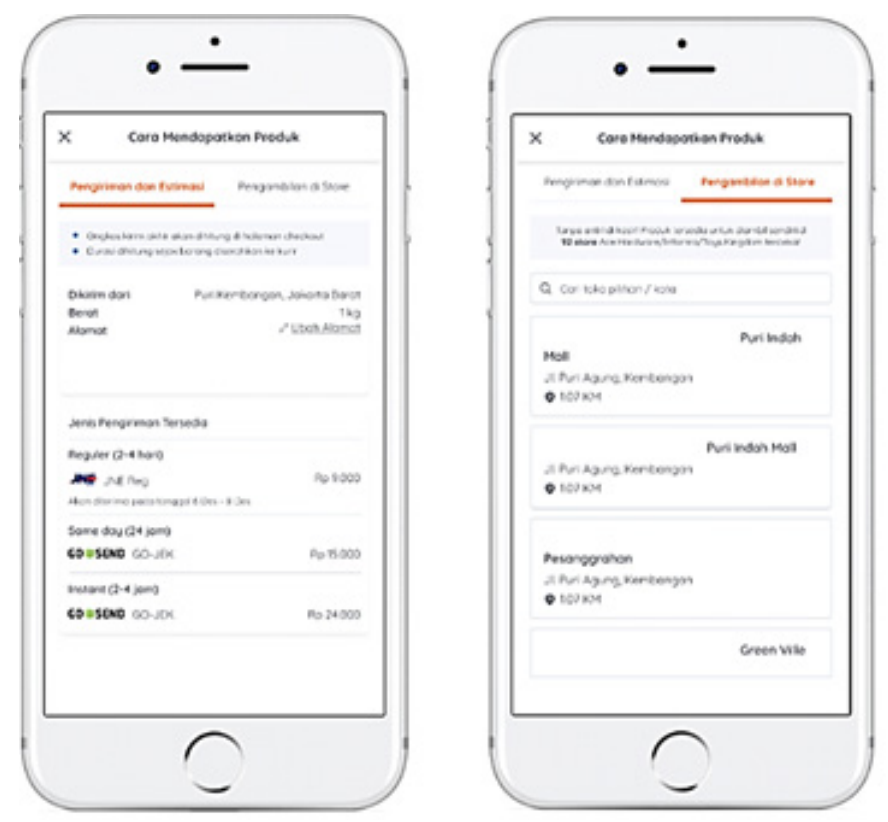

Figure 10 New User Interface for Delivery Information 
Question and answer are new features added to enrich information about a product. Every question related to the product will be displayed on this page. So, it can shorten the time the user has a question that he wants to ask. Figure 11 shows the feature.

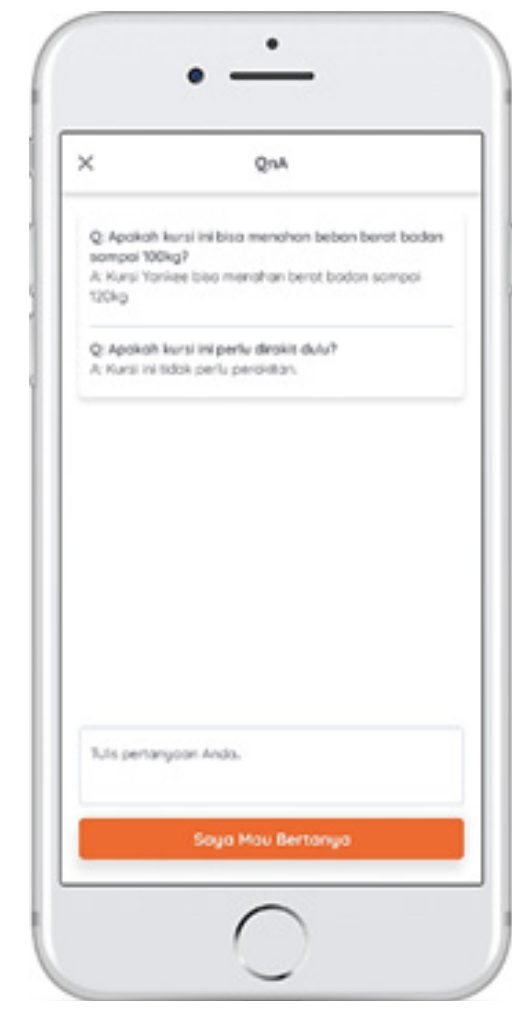

Figure 11 Question and Answer Feature

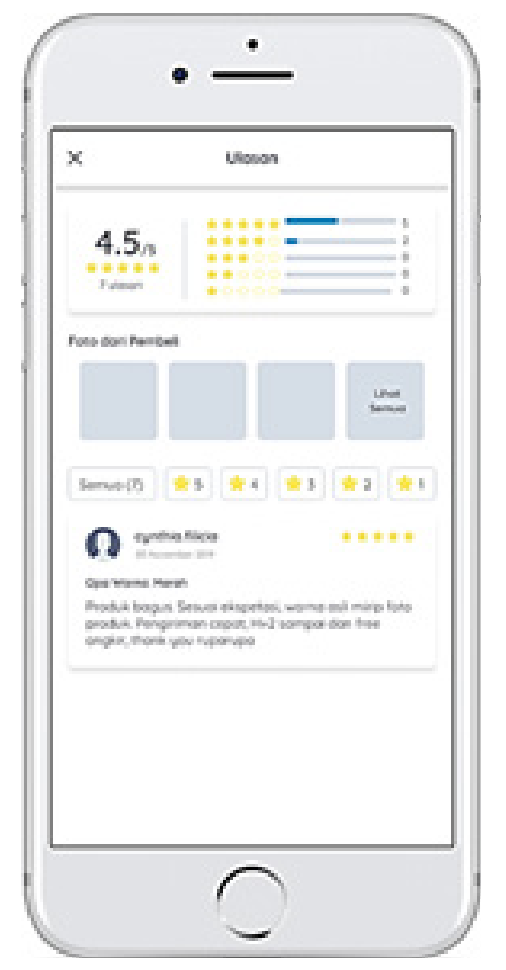

Figure 12 Review Feature
The last feature added is the review. In this feature, users can see reviews from other users who have bought the product. The reason for adding this feature is because users trust other users' reviews more than advertisers and marketers. RP2 can show users the average rating of a product and how many reviews are posted. To write a review, the users must have received the item, which later the order status will change to a review on the profile page. Then, the users will be directed to write a review. Figure 12 shows the review page.

\section{CONCLUSIONS}

A mobile application that is equipped with a good user experience will help users to adjust to the application more comfortably. Moreover, a beautifully designed user interface can be more attractive and help users to navigate the application. Hence, balancing function and visual appeal is essential to increase the level of user satisfaction and loyalty to an application.

From the results of the distributed UEQ, it obtains six aspects to be assessed. The six aspects still have a values below average, with novelty as the lowest value. Based on this information, researchers conduct more in-depth interviews with users and project leaders. From the three processes above, it can be concluded that the problems contained in the RP2 mobile application are the lack of quality user experience from this mobile application, many unavailable features, and the not well-ordered interface display.

Changes have been made to the RP2 mobile application using the design thinking method to solve this problem. Changes will be applied in several views such as home, navigation and notifications, search bar, product detail page, cart and payment, and profiles. With these changes, it is hoped that users of the RP2 mobile application will increase. Then, the number of transactions through the RP2 mobile application will also increase. It is also expected that the users can easily search for information and find the product they are looking for by adding new features. The research limitation is that the results of the research have not been retested to find out whether the user interface redesign has met the users' expectations. For further research, it can be done to perform usability testing on the RP2 mobile application.

\section{REFERENCES}

Asosiasi Penyelenggara Jasa Internet Indonesia. (2018). Hasil survei penetrasi dan perilaku pengguna Internet Indonesia 2018. Retrieved from https:// www.apjii.or.id/content/read/39/410/HasilSurvei-Penetrasi-dan-Perilaku-Pengguna-InternetIndonesia-2018

Bilgihan, A. (2016). Gen Y customer loyalty in online shopping: An integrated model of trust, user experience and branding. Computers in Human 
Behavior, 61, 103-113. https://doi.org/10.1016/j. chb.2016.03.014

Casare, A. R., Da Silva, C. G., Basso, T., \& Moraes, R. (2021). Towards usability interface trustworthiness in e-commerce systems. In International Conferences Interfaces and Human Computer Interaction 2021.

Dam, R. F., \& Siang, T. Y. (2020). What is design thinking and why is it so popular? Retrieved November $20^{\text {th }} 2020$ from https://www.interaction-design.org/ literature/article/what-is-design-thinking-and-whyis-it-so-popular

Kamran, R., \& Dal Cin, A. (2020). Designing a Mission Statement mobile app for palliative care: An innovation project utilizing design-thinking methodology. BMC Palliative Care, 19, 1-6. https:// doi.org/10.1186/s12904-020-00659-1

Kemp, S., \& Moey, S. (2019). Digital 2019 spotlight: Ecommerce in Indonesia. Retrieved July $23^{\text {rd }} 2020$ from https://datareportal.com/reports/digital-2019ecommerce-in-indonesia

Kumaresh, S., Haran, R., \& Jarret, M. M. (2021). Analytics of e-commerce platforms based on User-Experience (UX). In Intelligent Computing and Innovation on Data Science (pp. 309-318). Springer. https://doi. org/10.1007/978-981-16-3153-5_34

Mitchell, S. N. (2017). Why investing in UI design saves costs, increases revenue and retains customers. Retrieved February $8^{\text {th }} 2021$ from https:// uxplanet.org/why-investing-in-ui-design-savescosts-increases-revenue-and-retains-customersc762b78c0526

Mushthofa, D., Sabariah, M. K., \& Effendy, V. (2018). Modelling the user interface design pattern for designing Islamic e-commerce website using user centered design. AIP Conference Proceedings, 1977(1), 1-9. https://doi.org/10.1063/1.5042878
Pham, Y. D., Fucci, D., \& Maalej, W. (2018). A first implementation of a design thinking workshop during a mobile app development course project. In Proceedings of the $2^{\text {nd }}$ International Workshop on Software Engineering Education for Millennials - SEEM '18 (pp. 56-63). ACM Press. https://doi. org/10.1145/3194779.3194785

Schrepp, M., Hinderks, A., \& Thomaschewski, J. (2014). Applying the User Experience Questionnaire (UEQ) in different evaluation scenarios. In International Conference of Design, User Experience, and Usability (pp. 383-392). Springer. https://doi. org/10.1007/978-3-319-07668-3_37

Schrepp, M., Hinderks, A., \& Thomaschewski, J. (2017). Design and Evaluation of a Short Version of the User Experience Questionnaire (UEQ-S). International Journal of Interactive Multimedia and Artificial Intelligence, 4(6), 103-108. https://doi.org/10.9781/ ijimai.2017.09.001

Setiawan, A., Muna, A. N., Arumi, E. R., \& Sukmasetya, P. (2020). The growth electronic commerce technology and user interface in Indonesia. TEST Engineering and Management, 83(May-June 2020), 1681916827.

Tschimmel, K. (2012). Design thinking as an effective toolkit for innovation. In XXIII ISPIM Conference: Action for Innovation: Innovating from Experience (pp. 1-20). https://doi.org/10.13140/2.1.2570.3361

Valentim, N. M. C., Silva, W., \& Conte, T. (2017). The students' perspectives on applying design thinking for the design of mobile applications. In 2017 IEEE/ ACM 39th International Conference on Software Engineering: Software Engineering Education and Training Track (ICSE-SEET) (pp. 77-86). IEEE. https://doi.org/10.1109/ICSE-SEET.2017.10 


\section{APPENDIX}

Table 2 Proposed Solutions based on Research

\begin{tabular}{ll}
\hline Page & Problem \\
\hline Home & $\begin{array}{l}\text { The structure and organization of the home } \\
\text { page are less attractive and do not display } \\
\text { attention-grabbing items. } \\
\text { The process of searching for goods through the } \\
\text { category menu is less effective. } \\
\text { Home }\end{array}$ \\
Categories that appear when searching for \\
products with the search bar are too many and \\
take up space. \\
Home & $\begin{array}{l}\text { Categories on the home page are too many and } \\
\text { take up space. }\end{array}$ \\
Home & $\begin{array}{l}\text { Order status in the navigation bar is less } \\
\text { familiar. } \\
\text { "Howe }\end{array}$ \\
& on the home page.
\end{tabular}

Home Call center on the left is less helpful.

Home People's choice is less necessary.

Home It is difficult to view information on ongoing promotions.

Home Placeholder that exists in the search bar is less appropriate ("try a chair").

Solution

The appearance of the home page is improved by prioritizing the personalization of each user.

The category of each item has its page, and its subcategories are displayed on that page.

The search bar display is updated, and the categories on the search page are changed to the most searched popular categories.

Categories on the home page are made according to the categories that users see most often and are partially displayed with the option "See All".

It is moved to the account on the profile page.

"How we can help you today" is deleted and replaced with "there is something left out" to display the items that have been put into cart shopping but have not been checked out yet.

Call center in the top left header is removed. On the profile page, there is a chat feature with User Service (customer service).

People's choice is removed and replaced with wishlist and best-selling products.

A new page is made. It contains all ongoing promotions.

Placeholders are made to be more attractive so that users are more interested in looking for items.

Home The promo display in the home section does not attract attention.

Home displaying promo banners of brands and others are made to be more attractive and more compact with sliders for mobile users.

Home There are recommendations from project leaders.

The sections on the home are made according to each user's history (personalized).

Home There are recommendations from project leaders.

Home There are recommendations from project leaders.

Navigation There are recommendations from project leaders.

Search No search results appear with synonymous keywords in the search bar.

Search No search results appear if there is a misspelling in the search bar.

Search There are recommendations from project leaders.

Search There are recommendations from project leaders.

The navigation bar is added to the signature button, namely scanning the barcode in the middle.

The shopping cart on the home page is moved to navigation, and the notification feature is changed.

A scan button is added in the middle of the navigation for barcode scanning to make it more exposed to users. The results of the search show synonyms of keywords.

Search result corrections are added if there is a misspelling.

Popular searches on the search bar have an image display to make it more attractive.

Features of autocompleting are added when the users type something in the search bar.

Profile Profile page is less attractive and less complete. Profile page (account) is designed repeated by displaying the order, changed profile, store locator, wishlist, last-seen items, address of the delivery, and assistance and information that exist.

Profile Order status page looks simple and less attractive.

Profile There are recommendations from project leaders.

Design is improved with a more appealing and presentable look.

New features are added to the profile, namely store locator and last-seen item.

PCP Sub-categories that emerged from the results of The sub-categories that appear are made into sliders. search products are too much and take up space. 
Table 2 Proposed Solutions based on Research

(Continued)

\begin{tabular}{|c|c|c|}
\hline Page & Problem & Solution \\
\hline $\mathbf{P C P}$ & $\begin{array}{l}\text { The users cannot distinguish between brand and } \\
\text { item name. }\end{array}$ & Brand has its line. \\
\hline PCP & $\begin{array}{l}\text { The users are unable to know the number of filter } \\
\text { results. }\end{array}$ & The number of filter results is displayed. \\
\hline PCP & $\begin{array}{l}\text { The users do not know the color variations of the } \\
\text { products. }\end{array}$ & Color swatches are displayed. \\
\hline PCP & There are recommendations from project leaders. & $\begin{array}{l}\text { "Set Location" feature is added to display items that } \\
\text { are in certain locations only. Banners are also added } \\
\text { according to the selected category. }\end{array}$ \\
\hline PDP & $\begin{array}{l}\text { The users are unable to determine color } \\
\text { variations of the products. }\end{array}$ & Color swatches are displayed. \\
\hline PDP & The PDP display is too long. & $\begin{array}{l}\text { The PDP is divided into several sections (delivery, } \\
\text { questions and answers, and reviews). It also displays } \\
\text { some product information. }\end{array}$ \\
\hline PDP & $\begin{array}{l}\text { The product detail page is not neat in terms of } \\
\text { placement, fonts, and colors. }\end{array}$ & $\begin{array}{l}\text { System layout and placement of the divider are set } \\
\text { again. }\end{array}$ \\
\hline PDP & $\begin{array}{l}\text { There is no place to ask questions related to the } \\
\text { product. }\end{array}$ & $\begin{array}{l}\text { Page for questions and answers is provided so that the } \\
\text { users can ask questions, and the same questions cannot } \\
\text { be repeated. }\end{array}$ \\
\hline PDP & $\begin{array}{l}\text { There are no reviews, so users cannot find out } \\
\text { other people's ratings of the product. }\end{array}$ & A review page (rating and review) is created. \\
\hline PDP & $\begin{array}{l}\text { Information delivery is less obvious and not } \\
\text { interesting. }\end{array}$ & Delivery information has its page and is updated. \\
\hline PDP & There is no delivery estimation. & Delivery estimation is added. \\
\hline PDP & There are recommendations from project leaders. & $\begin{array}{l}\text { Item details, such as quantity and color, are determined } \\
\text { when the users want to add items to the basket. }\end{array}$ \\
\hline PDP & There are recommendations from project leaders. & $\begin{array}{l}\text { Detail of the product is minimized. It displays many } \\
\text { products at the bottom to accentuate other items there. }\end{array}$ \\
\hline PDP & There are recommendations from project leaders. & $\begin{array}{l}\text { The shipping page is divided into two tabs to highlight } \\
\text { shipping and collection methods. }\end{array}$ \\
\hline Cart & $\begin{array}{l}\text { The name of the checkout button is less familiar } \\
\text { to ordinary people. }\end{array}$ & $\begin{array}{l}\text { The name of the checkout button is changed into order } \\
\text { review. }\end{array}$ \\
\hline Payment & $\begin{array}{l}\text { The users do not know the estimated shipping } \\
\text { cost. }\end{array}$ & $\begin{array}{l}\text { The estimated shipping cost is displayed on the } \\
\text { payment page until delivery. }\end{array}$ \\
\hline Payment & $\begin{array}{l}\text { The location of the promo code is less clear and } \\
\text { familiar. }\end{array}$ & $\begin{array}{l}\text { Layout of the code promo is changed. The design is } \\
\text { zoomed in and placed on the top. }\end{array}$ \\
\hline Payment & $\begin{array}{l}\text { The feature of entering the address on each item } \\
\text { when purchasing is less visible and difficult to } \\
\text { understand. }\end{array}$ & $\begin{array}{l}\text { Features of some addresses are removed, so the users } \\
\text { are directed to choose the items that want to be sent to } \\
\text { a different address from the item checks. }\end{array}$ \\
\hline
\end{tabular}

PDP $=$ Product Detail Page \& PCP $=$ Product Catalog Page 